\title{
MINOR ÉS MAJOR PSZICHEDELIKUS SZERFOGYASZTÁS ÉS A HALÁLSZORONGÁS ÖSSZEFÜGGÉSEI
}

\author{
Ocsovszky Zsófia ${ }^{1}$ - Popovics Judit ${ }^{1}$ \\ ${ }^{1}$ KRE- Károli Gáspár Református Egyetem, Pszichológiai Intézet
}

\begin{abstract}
Absztrakt
Jelen kutatás a pszichedelikumok és a halálszorongás, valamint a koherencia-érzés öszszefüggéseit kutatja, érzelmi Stroop-teszt, Lester-féle halálszorongás skála és Antonovsky koherencia-érzés kérdőívének segítségével. Empirikus vizsgálatunk során azt igyekeztünk igazolni, hogy a pszichedelikumokat használók halálszorongása alacsonyabb, valamint koherencia érzésük magasabb a szert nem használók csoportjához viszonyítva. A 40 - 40 fős kísérleti mintában a használók csoportja további differenciálásra került használati prevalencia alapján. Szignifikáns eredményt kaptunk az Antonovsky-féle koherencia-érzés kérdőíven a szert nem használók javára az „értelmesség” alskálán. A Lester-féle halálszorongás teszt szintén szignifikáns eredményt hozott, itt is a nem használó csoport tagjai mutattak magasabb értéket. A korábbi kutatásokkal ellentmondó eredmények, a minta alacsony elemszáma, valamint egyéb,a kutatást korlátozó tényezők miatt további vizsgálat szükséges.
\end{abstract}

Kulcsszavak: pszichedelikumok • halálszorongás • egzisztenciális szorongás

\begin{abstract}
According to the self-administered questionnaires and research interviews psychoactive drug use shows decrease in death anxiety. This study aims to seek relationship between psychedelics, death anxiety and sense of coherence by using emotional Stroop test, Lester Attitude toward Death Scale and Sense of Coherence Scale. Our purpose was to verify that death anxiety lower and sense of coherence value is higher among the psychonauts than in the control group. The target group (40 drug users) and the control group (40 non-users) were further differentiated based on prevalence of use. Control group showed significantly higher result in the Sense of Coherence Scale and in the Meaningfulness sub scale. In the Lester Scale the target group showed significantly lower result. Conflicting results compared to previous studies, low number of the sample, as well as other research constraints requires further investigation.
\end{abstract}

Keywords: psychedelics • death • anxiety • existential anxiety 
'To fathom Hell or soar angelic, just take a pinch of psychedelic.'

(Humphry F. Osmond) ${ }^{1}$

A pszichedelikumok az ezredfordulót követően több tudományág kutatásainak középpontjába kerültek a pszichofarmakológiától kezdve a neuroimmunológián keresztül a pszichológiáig (Szummer, 2011a), a pszichiátriáig (Szummer, 2012 b), a tudatkutatásig (elmefilozófiáig) és a fenomenológiai filozófiáig (Szabó és mtsai, 2014, Szummer, 2015b, Horváth és mtsai, 2017). Többek között vizsgálták terminális rákos betegekkel halálfélelem/szorongás csökkentő hatásukat, illetve a hagyományos pszichoterápiát kiegészítve depresszió, szorongás, PTSD (poszttraumás stressz szindróma) kezelésére is sikerrel alkalmazták őket (Szummer, 2015a). Az eddig elért, terminális betegek halálfélelmének csökkentésére (Grof és Halifax, 1977a, Grof és Halifax, 1977b, Grof és mtsai, 1973), szorongáscsökkentésére (Gasser és mtsai, 2014) irányuló kutatási eredmények biztatók, ám a szer széleskörű pszichoterápiás használata még várat magára. Ennek nem kizárólag a még nem megfelelő számú empirikus és klinikai kutatás az oka, hanem a törvényi szabályozás is, amely a legtöbb országban a tiltott szerek listájára helyezi a pszichedelikumokat.

Az elméleti keretet gyakran jellemezték a transzperszonális megközelítések, amelyek mint vallásos-misztikus élményt fogták fel a pszichedelikus tapasztalatot (Szummer, 2015a). Jelen munka egy ritkán alkalmazott módot érvényesít: az egzisztenciális pszichoterápia paradigmájába helyezi a kérdéskört, ennek megfelelően a pszichedelikumokat mint a személyes növekedésre, önismeretre, létkérdésekkel való szembenézésre, legfőképpen pedig az egzisztenciális szorongás csökkentésére alkalmas eszközként vizsgálja. A pszichedelikumok egzisztenciális paradigmában való első hazai vizsgálatát 2015-ben Popovics Judit végezte el, kvalitatív módszerekkel (Popovics és mtsai, 2016). A pszichedelikumok halálszorongással való összefüggése kvantitatív módszerekkel mindezidáig sem hazai, sem pedig nemzetközi színtéren nem történt meg.

\section{A HALÁLSZORONGÁS AZ EGZISZTENCIÁLIS PSZICHOLÓGIA TÜKRÉBEN}

A halál témakörének pszichológiai vizsgálata során fontos különbséget tenni halálfélelem és halálszorongás között. A szorongás mentális készségeinket és cselekvéseinket irányító szerepe az egzisztencialista pszichológia/pszichoterápia központi gondolata. Kierkegaard az első olyan filozófus, aki a 19. század közepén - a hegeli gondolkodással szembefordulva - a szubjektumot mint egyedi emberi létezést, azaz egzisztenciát tematizálja. Ő tett először különbséget szo-

\footnotetext{
„Hogy pokol mélyére hatolj, vagy angyalként szállj, egy csipetnyi pszichedelikum az ár.” (saját fordítás)
} 
rongás és félelem között, valamint beszélt a szorongás pozitív aspektusáról is (Kirkegaard, 1969,1993). A 20. században Martin Heidegger az egzisztencialista ontológiát dolgozta ki mestere, Edmund Husserl fenomenológiai módszerét alkalmazva. 1927-ben megjelent Lét és idő címú munkájában vezeti be a Dasein fogalmát, aminek magyar fordítása: ittlét vagy jelenvaló lét. Heidegger ez alatt magát az embert érti, a világban való létet a maga természetességében és egyértelmüségében. Heidegger szerint a tárgyiasulásban, a földtől, a lényegtől való eltávolodás okozta ontológiai-egzisztenciális vákuumban magunkra is csak tárgyként gondolunk, éppúgy, mint más létezőkre, például egy asztalra, azonban így éppen a Dasein lényege vész el. A másokkal körülvett itt-lét egyik veszélye abban rejlik, hogy az arctalan tömeg, az akárki felemészti, és a saját részévé teszi az egyént, ezzel fosztva meg autentikusságától: a dasein úgy cselekszik, mint ahogy az akárki cselekedne a helyében. Az inautentikus létezésből kitörni csak a lét végső igazságának megértésével, a végességünkkel való szembenézéssel, véges lény mivoltunk elfogadásával lehet. Heidegger ezzel a halál filozófiai tematikáját állítja a fókuszba. A végesség tudata a halálhoz előrefutó lét. Halálunkkal érjük el az egzisztenciális teljességet, de ha meghaltunk, már nem vagyunk itt, hogy azt birtokolhassuk. Véges lény mivoltunk tudata emlékeztet bennünket arra, hogy magunkat nem birtokolhatjuk úgy, mint egy tárgyat. Csak az ezzel való szembesülés vezethet az autentikus léthez, az itt -és- most-ban való értelmes és teljes élethez (van Deurzen, 2009).

Az egzisztenciális pszichológia és pszichoterápia a kierkegaardi és heideggeri filozófiában gyökerezik. A lét végső kérdéseit állítja fókuszába, azt vizsgálja, hogyan küzdenek meg az emberek az egzisztenciális kérdésekkel, hogyan hatnak azok cselekvéseikre, életükre. Paul Tillich, a német származású Amerikába emigrált protestáns teológus kutatása rávilágít: az egzisztenciális szorongás mértéke pozitívan korrelál a tünetekkel depressziós és, szorongásos zavarokkal küzdő betegeknél (Tillich, 1952). Az egzisztenciális szorongás kora gyermekkorban megjelenik az ember életében, amikor először szembesül a halállal. Az elmúlás, a nem-lét ténye, árnyéka ettől kezdve olyan erős szorongást idéz elő, amit tudattalanunk minden erôvel igyekszik távol tartani, és ehhez elhárító mechanizmusokhoz folyamodik, például fontosságtudattal, munkamániával, vagy a saját különlegességünkbe vetett hittel igyekszik védeni magát. Tillich (1952) szerint a neurózis olyan megoldási kísérlet, „mely úgy kerüli el a nemlétet, hogy kerüli a létet”, azaz a hiteles létezést („Neurosis is the way of avoiding nonbeing by avoiding being.").

Az egzisztenciális szorongások empirikus vizsgálata a rettegéskezelés elmélet (ld. még: terrormenedzsment elmélet (Greenberg, 1986)) létrehozásával indult el, mára pedig népszerü kutatási paradigmává vált XXP, azaz Experimental Existential Psychology (Kísérleti Egzisztenciális Pszichológia) néven (Pyszczynski és mtsai, 2004). A rettegéskezelés elmélet magyarázatot kínál arra, miért szükséges az embernek értelmet adnia az életének, miért van szüksége önbecsülésre, 
és arra is keres választ, hogy miért konfliktusokkal és előitéletekkel terheltek az emberi találkozások (Pyszczynski és mtsai, 2004). E szerint a haláltól való félelmünk, szorongásunk meghatározza többek között világképünk megvédésének módját. Magasabb halálfélelemmel bírók vehemensebben védik világképüket, mivel a saját csoport, kultúra, ország adja fontosságuk tudatát, helyüket és fennmaradó nyomukat a világban. Haláluk után a csoport továbbra is fennmarad, így abba beágyazódva biztosíthatják maguk számára a kvázi-öröklétet (Békés, 2004).

Napjaink valószínúleg legismertebb csoport- és egyéni terapeutája, egyben vezető egzisztenciális pszichoterapeutája, Irvin D. Yalom. Kirkegaard, Heidegger, Sartre, Camus és Frankl egzisztencialista munkássága alapján egy viszonylag egyszerű elméleti konstrukciót hozott létre. Yalom négy összekapcsolódó, konvergáló egzisztenciális területet különít el: halál, magány/elszigetelődés, szabadság, értelemnélküliség. Sorsunk és világunk szabad alakításában a felelősség szorongató érzése, döntéseink vállalása elválaszt másoktól, és a létezés magányával, ontológiai szorongással (Kierkegaard fogalma) „ajándékoz” meg minket. A világ realitása („az asztal az asztal” vonatkoztatási rendszer egyszerüsége) biztonságot nyújt ugyan, azonban egyúttal korlátoz is; csak az ebből a komfortzónából való kilépés eredményez szabad, felelősségteljes életet. Fenti kérdések teljes elutasítása patológiához vezethetnek, úgy mint kényszerességhez, azaz olyan világ teremtéséhez, amelyben az egyén nem szabad, hanem egy külső erő által sürgetett kényszeres cselekvéssorozat rabja; vagy paranoiához, azaz a felelősség áttolásához másokra; illetve akár pszichoszomatikus betegségekhez (Yalom, 2006).

\section{A PSZICHEDELIKUS ÉLMÉNY HATÁSA AZ EGZISZTENCIÁLIS SZORONGÁSRA ÉS A HALÁLFÉLELEMRE}

A pszichedelikumok az éber normál hétköznapi tudatállapottól radikálisan különböző tudatállapotot hoznak létre. A pszichedelikus szereket sokféle névvel illeti a szakirodalom: enteogének, pszichotomimetikumok, hallucinogének (Simon, 2009; Szummer, 2015; Móró és mtsai, 2011). A nevek természetesen nem értéksemlegesek. Az enteogén szó a spirituális, a pszichotomimetikum (pszichózist utánzó, pszichotikus tüneteket kiváltó) a pszichiátriai, a hallucinogén pedig a percepciós hatásokat emeli ki. Ennek mintájára képezhetnénk az „,autentogének” terminust is. Számos kutató véli úgy - köztük Hofmann, az LSD feltalálója, Pahnke (1963,1966,1969), Gasser (2014), Grob (2007, 2011) - hogy a „hallucinogén" szerek ideális körülmények között, ellenőrzött felhasználás mellett rendelkeznek olyan potenciállal, ami az emberi psziché különböző szintjein zajló egyébként láthatatlan tudati folyamatok hozzáféréséhez segítheti hozzá a pszichonautát ${ }^{2}$.

Lásd később a fogalom meghatározását! 
A pszichedelikus szerek terápiás alkalmazása a pszichoterápia „klasszikus eszközei”-től (álom /álomelemzés, imagináció) eltérnek, mintegy új eszközként jelenhetnek meg a terápia támogatására. A pszichedelikus élmény tisztább, világosabb kontúrokat, pontosabb felidézést nyújt, az MDMA esetében pedig nagyobb bizalom jön létre a kliens és a terapeuta között. Mindezeken túl, a pszichedelikumok, az álomtól és imaginációtól eltérően egyfajta misztikus élményhez juttatja a használót, ami igen erős, „, a világgal, a mindenséggel egységben levés" érzését adja. (l.d. később Grof és Grob kísérleti eredményeit).

Hazánkban a pszichedelikumokkal való kísérletek az 1950-es évek közepén kezdődtek el. Az Országos Ideg- és Elmegyógyintézet munkaközössége (tagjai: Böszörményi Zoltán, Brunecker Györgyi, Szára István, Sai-Halász András) triptamin származékokat használt kutatásaiban $(1958,1968)$. Böszörményiék már az ötvenes évek közepén felismerték a set és setting ${ }^{3}$ problematikáját. 195668 között több kísérletet folytattak szkizofrén és egyéb pszichotikus páciensekkel kontrollcsoportos összehasonlításban. DMT ${ }^{4}$ vizsgálataikkal világelsők voltak. 1966-ban Timothy Leary ezen magyar kísérletekre alapozva (Leary, 1966), majd 1976-ban Gillin és munkatársai (1976), szintén a Böszörményi-kutatócsoport eredményeire (1963) támaszkodva erősítették meg publikációjukat. Böszörményiék a pszichotikus betegek csökkent reakcióját feltételezett endogén DMT szintézissel magyarázták (Rappant,1999/2002).

Stanislav Grof cseh származású amerikai pszichiáter, a mai transzperszonális kutatások vezéralakja a kora 60-as években kezdte meg LSD-kísérleteit. Vizsgálataiban hatalmas adagokat - 1200-1500 mikrogramm - használt. Megfigyelte, hogy legtöbb alanya haláláról és újjászületéséről számol be, mely tapasztalást általában „kozmikus egységérzés” követ, valamint megfigyelhető a halál iránti attitűd és halálkoncepció drámai változása a szerhasználatot követően. A saját haláltól való félelem megszünt, és a halálra inkább, mint érdekes kalandra, semmint végső tragédiára utaltak a kliensek (Grof és mtsai, 1977). Ezek az első beszámolók vezettek rákos és egyéb, terminális betegségben szenvedők halálszorongásának csökkentésére irányuló kísérleti terápiákhoz. E módszer úttörője Walter Pahnke volt, aki az 1963-ban a Harvard Egyetemen teológus hallgatókkal folytatott kutatásának eredményeivel (Marsh Chapel vagy ismertebb nevén Good Friday kísérlet) bebizonyította, hogy a pszilocibin misztikus élményt képes kiváltani. Pahnke, búvárbalesetben bekövetkezett haláláig, 1973-ig vezette a Spring Grove Kórház Kutatási részlegében folytatott vizsgálatokat; halála után Grof vette át a projekt irányítását egészen 1974-ig, amit akkor adminisztratív nyomásra leállítottak. A Spring Grove kutatócsapatához 1972-ben Grof akkori felesége, a kultúrantropológus Joan Halifax is csatlakozott. A kísérletek

3 Set és setting (azaz lelkiállapot és környezet) a két legfontosabb tényezők a pszichedelikus élmény során, amik nagyban befolysáolják az utazás kimenetelét.

$4 \quad N, N$-dimetiltriptamin (dimetiltriptamin, $N, N$-DMT vagy DMT) a triptaminok közé tartozó pszichoaktív alkaloid, intenzív hallucinogén. 
szerint a rákos betegekkel folytatott LSD-vel támogatott pszichoterápia csökkentette a fájdalmat, és nagymértékben a halállal kapcsolatos szorongásokat is, a terminális állapottal szembeni elfogadást pedig növelte (Grof és mtasi, 1978; Goodman és mtsai, 1973).

A 60-as évek közepétől 1990-ig Amerikában gyakorlatilag lehetetlen volt pszichedelikus kutatásra humán alanyokon engedélyt kapni. Két évtized kényszerű moratóriuma után Rick Strassman amerikai kutató pszichiáter projektje kapott először zöld utat (Strassman és mtsai, 1996; 2001) és ezzel elindította az ezredforduló pszichedelikus reneszánszát (Szummer, 2017). Charles Grob Stanislav Grof kutatásaira alapozva kezdte meg a The Harbor-UCLA Psilocybin Treatment of Cancer Anxiety Project-et 2004-ben. A terminális betegekkel végzett kettős-vak kísérletet élményfeldolgozás, élményintegráció követte. Grob (2007, 2011) eredményként említi a szorongás csökkenését, a közeli hozzátartozókkal való jobb, közelibb kapcsolatot, valamint arról is beszámol, hogy a kísérletben résztvevők egyfajta „ontológiai biztonságot” éreztek még a 2011-es kísérletben is, ahol kisebb dózisokkal dolgoztak.

Peter Gasser (2014) svájci kettős-vak vizsgálatában a STAI ${ }^{5}$ (State-Trait Anxiety Inventory) értékek hosszútávú változását követte LSD-asszisztált pszichoterápiával kezelt, szintén terminális stádiumú betegeknél. Empirikus adatai azt mutatják, hogy a tíz ülés után csökkenő STAI érték legalább 12 hónapig fennmaradt a kísérletbe bevont személyeknél. Félig strukturált interjúval egészítette ki megfigyeléseit, melyek során a kísérleti személyek 77.8\%-a számolt be szorongás, és halállal kapcsolatos szorongásainak mérséklődéséről (ld. 1. ábra, kiemeléssel).

1. ábra. Gasser kísérleti eredménye hosszútávú LSD terápia után.

A félig- strukturált interjú keretében a kliensek 77,8\%-a számol be csökkent szorongásról és halálfélelemről (2014)

Az LSD hatásai terápiás helyzetben

\begin{tabular}{lc}
\hline HATÁS & $\%$ \\
\hline Érzelmekhez való hozzáférés facilitációja & 66,7 \\
Introspekció, befelé figyelés & 66,7 \\
Gyorsabb haladás & 44,4 \\
Könnyebb elengedés & 33,3 \\
\hline Résztvevők által említett tartósan fennmaradó előnyök & \\
Pszichopatológiára gyakorolt hatás & 33,3 \\
\hline
\end{tabular}

$5 \quad$ A STAI tesztnek Magyarországon egy időben hibás változata is közkézen forgott, lásd Szigethy Klára, Takács Szabolcs: Figyelemfelhívás egy hibás publikációra és javaslat korrekcióra. Psychologia Hungarica Caroliensis, 3:(2) pp. 56-62. (2016) 


\section{Csökkent szorongás/ halálfélelem}

77.8

Egyéb, javuló tendenciát mutató pszichopatológiák, szimptómák

(beleértve jobb minőségű alvás, suicid gondolatok megszűnése, kevesebb depressziv érzés)

Pozitív pszichológiai hatás

\begin{tabular}{lc} 
Nyugodtabb, kipihentebb & 55,6 \\
Fizikális jóllét & 44,4 \\
Megnövekedett életminőség & 66,7 \\
Megnövekedett tudatosság & 44,4 \\
Megnövekedett nyugalom-érzés & 33,3 \\
Megnövekedett magabiztosság & 33,3 \\
Megnövekedett képesség a határok legyőzésére & 33,3 \\
Megnövekedett lelki erő & 22,2 \\
Szokások megváltozása & \\
Csökkent karrier- központúság & 33,3 \\
Megnövekedett türelem & 22,2 \\
Család fontosságának növekedése & 22,2 \\
véb személyiségbeli, értékbeli változás & 22,2 \\
\hline degában foglalja a csökkent anyagiasság, kevésbé én-központú, megnöve- & 66,7 \\
\hline
\end{tabular}

A félig-strukturált interjúk kvantitív értékelése (Forrás: Gasser, 2014)

Ahogyan a bevezetőben említettük: egészséges (nem terminális stádiumban lévő) pszichedelikum-használók halálattitűdjével, halálszorongásával foglalkozó kutatási eredményeket eddig nem publikáltak, jóllehet, a Johns Hopkins Egyetemen 2015-ben indult egy nagy nemzetközi vizsgálat ebben a témakörben. Az elektronikus kérdőíves adatfelvétel során (szabadszöveges és eldöntendő kérdéseket kell megválaszolni jórészt a setting-re vonatkozóan) arra kíváncsiak, hogy pszichedelikum használat után be tudnak-e számolni az alanyok halállal, haldokolással kapcsolatos meggyőződéseik, hitük megváltozásáról. Az adatgyűjtési fázisban lévő kutatás részletei, eredményei egyelőre nem nyilvánosak.

Fontos kiemelni, hogy jelen tanulmányban pusztán annak összefüggéseit kerestük, hogy van-e, és ha igen milyen együttjárás a pszichedelikum-használat és a halálszorongás között. Azonban lényeges kitérni arra is, hogy szükséges-e egyáltalán, illetve mikor szükséges a halálszorongást csökkenteni? A szorongás csökkentése kiemelten fontos lehet terminális betegek esetében, akik utolsó heteinek, hónapjainak minőségét nagyban meghatározza a közelgő halál okozta félelem distresszt, depressziót okozva, akadályozva a harmonikus „világban- 
benne létet”, meggátolva, vagy megnehezítve a ,jó halál” tapasztalatát. Ugyanez érvényes a patológiás halálszorongásra is. Azonban a hedeggeri halál-felévaló-lét szorongásának csökkentése nem cél, hiszen az már nem segíti az autentikus létezést, hanem létfeledés állapotába juttatná az egyént.

\section{A PSZICHEDELIKUS ÉLMÉNYKERESÉS ÉS A PSZICHOLÓGIAI IMMUNRENDSZER}

Minden pszichedelikus élmény egyedülálló és megismételhetetlen, a beszámolók alapján mégis rendelkeznek valamilyen közös mintázattal. A szerhasználók meglepően gyakran (szerek között különbségek azonban lehetnek) számolnak be spirituális és misztikus egységélményről, egyfajta unio mysticáról, amelyet a világ különböző vallási tradícióihoz tartozó misztikus szerzők is gyakran említenek (Szummer, 2015). A beszámolókban rendre megjelennek közelségről, intenzív érzelmi kapcsolódásról a többi emberhez és a természethez, vagy felfokozódott szeretet-érzésről (pl. „szeretet-energia” áradásáról, az abban való feloldódásról), a világ megértésének illúziójáról szóló narratívák is. Az is megfigyelhető ezekben, hogy gyakran bukkannak fel a halállal, szenvedéssel, fájdalommal kapcsolatos archetipikus képek, amelyek az egzisztenciális kérdések felvetődését és megválaszolását hívják elő a pszichedelikus tapasztalat során (Houston és mtsai, 1966; Mirnics, 2016). Mindezen élmények azonban eltünnek azok integrációja nélkül. ${ }^{6}$

A pszichedelikus utazás megfelelő rákészüléssel, pszichés állapottal (set) és a gondosan kialakított környezettel (setting) eredményezhet mélyebb spirituális ébredést (Móró és mtsai, 2011). Számos szerhasználó éppen ezt az élményt keresi, ók az önismereti és spirituális célú szerfogyasztók, a szakirodalom „pszichonautáknak” nevezi őket. Móróék empirikus módszerekkel igazolták ezen sajátos felhasználói csoportnak a létezését, és ennek kapcsán rámutattak a konvencionális droghasználati modellek differenciálatlan voltára. Móróék (2011) Antonovsky salutogenezis modelljét ${ }^{7}$ használták tanulmányukban, amely az önfejlesztés-célú pszichedelikum használat jelenségét járja körül. Kutatásuk szerint szerhasználók és nem használók között nemcsak spiritualitás tekintetében (PIK spiritualitás alskálán) mutatható ki szignifikáns különbség, hanem a vizsgálati személyek által megjelölt droghasználati cél tekintetében is: a pszichedelikumokat használók az önismereti, spirituális célt, míg más szert használók a szerhasználat rekreációs jellegét hangsúlyozták. A droghasználati

\footnotetext{
6 Szummer (2015a) a freud-i álomelmélet (Freud, 1900/1985) „másodlagos megmunkálásához” hasonlítja a pszichedelikus élményekről alkotott verbális beszámolókban megjelenő rendezettséget.

A salutogenezis-modell az egyén megküzdő képességét, a pszichés immunrendszert állítja fókuszba. Azokat a lelki erősorráfsokat, melyekez az egyén az egészsége fenntartása érdekében mozgósítani tud.
} 
szakirodalom szerint a vallás, spiritualitás védőfaktorként szolgálhat a droghasználat ellen, Móróék (2011) tanulmánya azonban ezt árnyalja: a vallás, a spiritualitás a problémás szerhasználatnak, nem pedig a droghasználatnak lehet védőfaktora.

Lerner és Lyvers (2006) többek között a 29 itemes Koherencia-érzés skálát használták három csoportos összehasonlításukban (nem pszichedelikus droghasználók, pszichedelikus szerhasználók és nem szerhasználók), ez szignifikáns különbséget mutatott a nem pszichedelikus droghasználók és a másik két csoport között, és mediánban eltérést mutatott a pszichedelikum használók és a kontroll csoport között, előbbiek javára magasabb értéket jelezve. A használók a Mystical Beliefs Questionnaire (MBQ)-en szignifikánsan magasabb értéket mutattak, ami összefüggésben állhat a stresszel való megküzdés sikerességében, így közvetlenül befolyásolhatja a koherencia-érzést.

\section{JELEN KUTATÁS CÉLJA}

Jelen kutatás igyekszik körüljárni a pszichedelikumok halálszorongásra gyakorolt hatását. Feltételeztük - kiindulva a személyes beszámolókból, illetve Grof (2011) és Grob (2007) kutatásaiból - hogy a pszichedelikus utazás során megtapasztalt kvázi-misztikus élmények (Szummer 2010; 2011a; 2015; Popovics és mtsai, 2016) egzisztenciális kérdésekkel való szembesülést váltanak ki, az egységélmény (ego feloldódása, halála, az énhatárok elmosódása) pedig olyan tapasztalásokhoz juttatja a szerhasználót, amelyek sikerrel képesek csökkenteni az egzisztenciális szorongásokat. Ezek a felsorolt konstruktumok azonban meglehetősen nehezen mérhetők, így a téma differenciált vizsgálatot kíván. Ennek első lépéseként kívánjuk jelen kutatás során, a pszichedelikum-használat és a halálszorongás közötti összefüggéseket kimutatni, valamint megismételni korábbi kutatások eredményét a pszichedelikum-használat és a koherencia-érzék között. Kutatásunk reményeink szerint hozzájárul és illeszkedik a pszichedelikus szerek lehetséges jövőbeni pszichoterápiás alkalmazásához szükséges empirikus tapasztalatgyüjtések sorába.

\section{MÓDSZEREK ÉS RÉSZTVEVŐK}

A kérdőívcsomag kitöltéséhez pszichedelikus szerhasználókat (a továbbiakban pszich csoport, $\mathrm{n}=40$ ) és ugyanolyan elemszámban nem használókat, kontroll csoportot (a továbbiakban kontroll, $\mathrm{n}=40$ ) hívtunk meg. A kontrollcsoport tagjait ismerősök közül, hólabda módszerrel, interneten keresztül toboroztuk. A résztvevők a kutatásban való részvételért fizetséget nem kaptak. Demográfiai kitételek nem voltak. 
A statisztikai próbákat három elrendezésben futtattuk le:

1. Teljes csoport: pszich $n=40$, kontroll $n=40$

2.Differenciált csoport: a pszich csoportot használati prevalencia alapján, tovább osztottuk legtöbbet használók (39 vagy több használati alkalom) és közepes használókra (38-14 közötti használat), így 3 vizsgálati csoportot kaptunk (legtöbbet $n=20$, közepes $n=20$, kontroll=40). A differenciálás módszertani alapját az a törekvés adta, hogy egyenlő elemszámú csoportokat hozzunk létre.

3.Vágott csoport: kiválasztottuk a 12 legtöbbet használót és nemi csoportillesztéssel hozzárendeltünk 12 kontrollt.

34 nő, 46 férfi vett részt a kutatásban. A pszich csoportban: 4 nő, 36 férfi, a kontroll csoportban 31 nő, 9 férfi volt.

\section{VIZSGÁLATI ESZKÖZÖK ÉS ANYAGOK}

A statisztikai adatfeldolgozás során Vargha András: Matematikai Statisztika könyvének metodikáját, a technikai megvalósításnál pedig Takács Szabolcs Statisztikai segédanyag mühelymunkákhoz, szakdolgozatok elektronikus könyvének eljárásait követtük (Vargha, 2000; Takács, 2016).

A vizsgálathoz egy ehhez a kutatáshoz dedikált elektronikus tesztfelületet hoztunk létre egyedi programozással. A rendszer a válaszadóktól semmilyen személyes adatot nem kér, a kitöltők egy véletlenszerúen generált számkód alapján kerültek be az adatbázisba, ami azonosításra semmilyen módon nem alkalmas.

\section{ÉRZELMI STROOP}

A halálszorongás nem explicit, tetten érhető érzés, papír-ceruza teszttel nem mérhető. Ezért olyan mérőeszközt igyekeztünk választani, ami nem direkt módon kérdez rá a halállal kapcsolatos félelmekre, hanem indirekt módon próbálja az ezzel kapcsolatos attitűdöt feltérképezni.

Az érzelmi Stroop koncepciója (Williams és Matthews, 2006, Watts és mtsai, 1986), különbözik a klasszikus szín-szó teszttől, ugyanis habár a feladat itt is az, hogy a kísérleti személyek megnevezzék (kiválasszák) a színt, amellyel az érzelmet előhívó szavakat látják a képernyőn, azonban itt a szavak a színekkel nem állnak kapcsolatban. A negatív szavakra adott megnövekedett reakcióidő arra utal, hogy az olvasás interferál az érzelmi feldolgozással, azaz hogy a személy figyelmét az ingerszó jobban lekötötte. Újabb kutatások szerint az érzelmi Stroop-hatásnak az alapja sokkal inkább annak a jelenségnek a következménye, hogy jelentősebb érzelmi hatásra lelassul a szemantikus feldolgozás. Ez a jelenség a „fenyegetésvezérelt lelassulás” (Algom és mtsai, 2004). 
Larsen és munkatársai (2006), valamint Demily (2010) és munkatársai kutatási eredményei azt mutatják, hogy negatív érzelmi töltettel rendelkező szavak esetében megnő a válaszidő a semlegesekhez képest, míg a pozitív töltetű szavaknál nincs szignifikáns eltérés.

\section{Az érzelmi Stroop teszt programozása}

A teszt ingeranyaga 3×25 szóból és további 25 kontrollkarakterből áll. Az ingerszavak véletlenszerü sorrendben és színben egymás után jelennek meg. Tévesztés esetén a képernyőn hiba figyelmeztető szó jelenik meg, új szót kap a résztvevő; a rendszer jegyzi a hibázások számát. Hogy minden válaszadó esetén azonos mennyiségú jó választ kapjunk, a hibás válaszok számával megnövelt ingerszót kap a tévesztő.

Az ingerszavak összeállításánál figyeltünk a szavak hosszára, hogy a hosszabb szavak ne torzíthassák a reakcióidőt.

A színgombok elhelyezkedésénél a programozás során hangsúlyt fektettünk arra is, hogy azok elérési ideje nagyjából egyforma legyen, az egyéni egérhasználati szokásokat is figyelembe véve.

A kiértékelés az ingerszavakra adott reakcióidő alap-

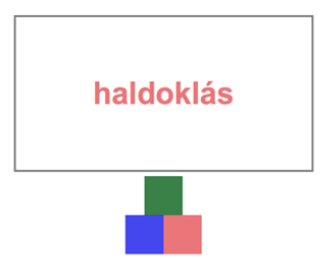

2. ábra. Egy példa az

Érzelmi Stroop tesztből ján történt, amit minden esetben jegyez a rendszer. Az adattáblába a negatív, halállal kapcsolatos szavakra adott reakcióidő és a semleges szavakra adott reakcióidő különbsége, mint Stroop-interferencia (a negatív valenciájú szavakra adott megnövekedett reakcióidő értéke) érték került be.

\section{LESTER HALÁL IRÁNTI ATTITƯD SKÁLA}

A 21 tételből álló, egydimenziós skálát Lester 1991-ben validálta, angol nyelven. A skála megbízhatóságát mérő test-retest reliabilitás vizsgálat során a Spearmanféle rangkorreláció o,58-as eredményt hozott. A hat hét különbséggel vizsgált nyolcvan diák két felmérése között a Spearman-féle rangkorreláció 0,70 volt a halál iránti attitűd pontértékében (Lester, 1991; Tóthné, 2009).

A skálát az különbözteti meg a többi halálfélelem papír-ceruza teszttől, hogy a tételek sorba rendezhetők úgy is, hogy kifejezzék a halál iránti általános attitűdöt, valamint a skála alkalmas a válaszadó tudatos (elfogadott) halál iránti attitűdtartományának mérésére is. A két mérés közötti különbség így a válaszadó következetlenségeit is mérhetővé teszi (Tóthné, 2009). 
Tehát a válaszadó két pontszámot kap:

Az eredeti Lester- publikációban minden tétel mellett szerepel egy számérték is, ezek adják a számítás alapját.

1. a halálattitűd pontot, ami a saját halál elfogadásának mértékét mutatja. Ezt a válaszadó igen-nel válaszolt kérdéseinek átlaga adja.

2. a tudatos (azaz elfogadott) halál iránti attitűd, ami azon tételekkel mérhető a skála- kontinuumon, amelyekkel a válaszadó egyetértett.

A skála magyar nyelvű fordítását és validálását 2005- 2009 között Tóthné Zana Ágnes és munkatársai végezték (2009).

A végső adattáblába a Lester totál, azaz az átlagos halálattitűd pontszám került be.

Tóthné és mtsai (2009) a Lester skála reliabilitás vizsgálata során a teljes tételsort figyelembe véve o,60 Cronbach-alfa értéket mértek.

\section{SOC- 13: RÖVIDÍTETT KOHERENCIA-ÉRZÉS SKÁLA (SENSE OF COHERENCE SCALE)}

A kérdőív azt az egyénben lévő erőforrást méri, amit az egyén képes mozgósítani a stresszorokkal szemben az egészsége megvédése érdekében. A koherencia-érzés szoros összefüggést mutat az egészséggel, a vélt egészséggel, és előre jelzi a szubjektív egészségi állapotot (Balajti és mtsai,2007). A koherencia-érzés egy abbéli hit, hogy a dolgok jól alakulnak, és az életnek értelme van. Védelmi tényezőként hozzájárul a hatékonyabb pszichológiai múködéshez, így a jobb életminőséghez, egyfajta pszichológiai immunrendszerként is felfogható (Antonovsky, 1987).

A kérdőív hosszabb formája 29 itemet tartalmaz, kutatásunkban a rövidített, 13 itemeset használtuk. Ennek magyarra fordítását, hazai adaptálását Balajti Ilona és munkatársai végezték, 2007-ben. A rövidített skála kérdéseire 7 pontos Likert-skálán kell jelölnie válaszait a kitöltőnek (nagyon ritkán vagy soha <-> nagyon gyakran; sohasem<->mindig) az élete eseményeire rákérdező kérdésekre. A szalutogenezis modellt követve a teszt 3 alskálából áll, az alábbiak szerint:

1) 2,6,8,9,11-es tétel: az élethelyzet átélt érthetősége (comprehensibility)

2) 3,5,10,13-as tétel: az életproblémák reálisként érzett kezelhetősége (manageability)

3) 1,4,7,12-es tétel: mindezen adottságok számunka való értelme illetve értéke (meaningfulness)

Fordított tételek: 1,2,3,7, 10, így 13-91 pont érhető el a teszten (Eriksson és Lindstrom 2005, idézi Balajti, 2007).

Balajti Ilona és munkatársai (2007) mérése szerint a válaszok belső konzisztenciája 0,82 (Cronbach-alfa érték), amely érték beleesik a rövidített kérdőív meta-analízise során talált 0,70-0,92 közötti értéktartományba. 


\section{A VIZSGÁLATI ELJÁRÁS}

A kitöltókkel közvetlen kapcsolatba nem kerültünk, a vizsgálatban való részvétel anonim volt, a résztvevőkről semmilyen személyes adat begyưjtésre, tárolásra nem került. A demográfiai adatok kitöltése után a fent ismertetett sorrendben történt a tesztek felvétele. A kitöltő program a válaszadókat véletlenszerủ azonosítóval látta el és SQL adatbázisba rögzítette. Minden teszt előtt részletes instrukciót kaptak a válaszadók a teszt kitöltésére és a program múködésére, irányítására vonatkozóan. A kitöltés nagyjából 10 percet vett igénybe.

\section{EREDMÉNYEK}

\section{III.1 Adatfeldolgozás, felhasznált statisztikai módszerek}

Az adatokat ROPstat 1.o programcsomaggal dolgoztuk fel, többféle statisztikai módszerrel.

A hagyományos próbák helyetti robusztus - vagy sztochasztikus összehasonlításokat igénylő - eljárásokat részint a már korábban említett Vargha-könyv, részint pedig Takács Szabolcs Érzékenységvizsgálatok a statisztikai eljárásokban című cikke alapján választottuk (Takács, 2012).

A pszich csoportot szétválasztása előtt (szétválasztás módszertanát ld. fent) egyben kezeltük, és a nagyszámú kitöltők közül véletlenszerűen válogattunk be résztvevőket a mintába. Ebben az esetben a csoportok közötti összehasonlításra a kétmintás t-próbát, normalitás sérülése esetén a Mann-Whitney-próbát, elméleti szórás sérülése esetén pedig Welch-d-próbát alkalmaztuk.

A pszich csoport differenciálása után (ezen túl differenciált csoport, szétválasztás módszertanát ld. fent) egyszempontos független mintás varianciaanalízist használtunk majd a 12 legtöbbet használót („vágott” csoport) kiválogattuk és ismét kétmintás t-próbát végeztünk, normalitás, elméleti szórás sérülése esetén robosztus próbákat alkalmaztunk.

A változók normalitásának elemzését a mintán ferdeség és csúcsosság alapján végeztük. Szóráshomogenitás tesztelésére pedig a Welch-féle Levene-próbát alkalmaztuk.

\section{Eredmények}

Első hipotézisünk szerint az érzelmi Stroop tesztben (William és mtsai, 1986,1996; Watts és mtsai, 1986) mért reakcióidő (Stroop interferencia) a pszichedelikus szert használók esetében alacsonyabb értéket mutat majd. 
A teljes csoportban a kétmintás t-próbát nem tudtuk alkalmazni, mert a ferdeség és csúcsosság alapján a vizsgált változók normalitása sérült. A MannWhitney-próba alkalmazása során a rangszórások homogenitása nem sérült (Levene-féle $\mathrm{F}(1,78)=1,024, \mathrm{p}=0,3147$ ). Mann-Whitney-próba (normális közelítés): $\mathrm{Z}=0,212(\mathrm{p}=0,832)$.

A differenciált csoportos varianciaanalízis eredménye sem mutatott szignifikanciát. Itt a szóráshomogenitás nem, míg a normalitás sérült, így KruskalWallis-próbát végeztünk, melynek eredménye: $\mathrm{H}(2)=0461(\mathrm{p}=0,7943)$.

Kétmintás-t-próbát a vágott csoportban a csúcsosság alapján a normalitás sérülése miatt nem tudtunk végezni. A Mann-Whitney-próba alkalmazása során a rangszórások homogenitása nem sérült (Levene-féle $\mathrm{F}(1 ; 22,0)=2,101(\mathrm{p}=0,1613))$. Eredménye: Mann-Whitney-próba (normális közelítés) $Z=-0,462(p=0,644)$.

A következő hipotézisünk, miszerint a pszichedelikus szert használók a Lester-féle halálszorongás skáláján (Lester, 1991; Tóthné, 2009) kapott értékei alacsonyabbak lesznek a szert sosem próbálókéhoz képest vágott csoport esetében szignifikáns eredményt mutatott.

A skála összértékeinek tekintetében teljes csoportban kétmintás-t-próbát alkalmazva nem tudtunk kimutatni szignifikáns különbséget. Tekintettel arra, hogy sem a normalitás, sem pedig az elméleti szórás nem sérült, kétmintás t-próbát alkalmaztunk, melynek eredménye: $\mathrm{t}(78)=-0,885(\mathrm{p}=0,3791)$.

A differenciált csoportos varianciaanalízis eredménye sem mutatott szignifikáns eredményt. $\mathrm{F}(2 ; 77)=0,829(\mathrm{p}=0$,4402). Érdemes azonban megjegyezni, hogy átlagok tekintetében a keveset fogyasztók mutatták a legalacsonyabb átlagértéket a Lester-féle halálszorongás skálán (ld. 3. ábra lent).

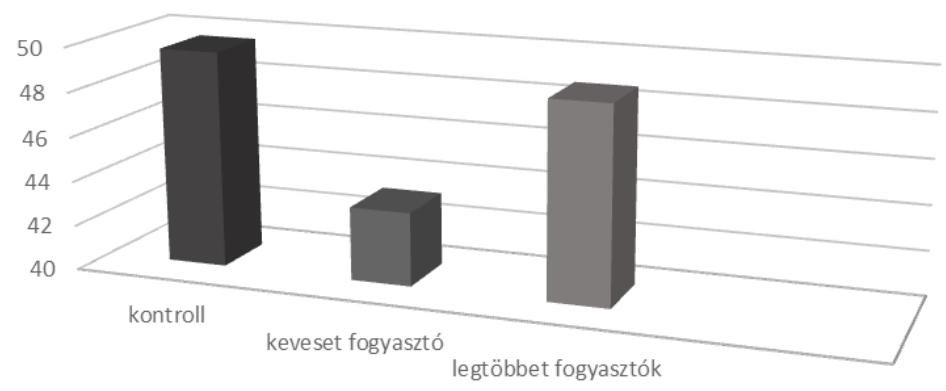

3. ábra. Lester-féle halálszorongás skála átlagai differenciált csoportban

A vágott csoport esetén a kétmintás-t-próba szignifikanciát: $\mathrm{t}(22)=-2,532$ (p = 0,0190)* jelzett (ld. 4. ábra). 


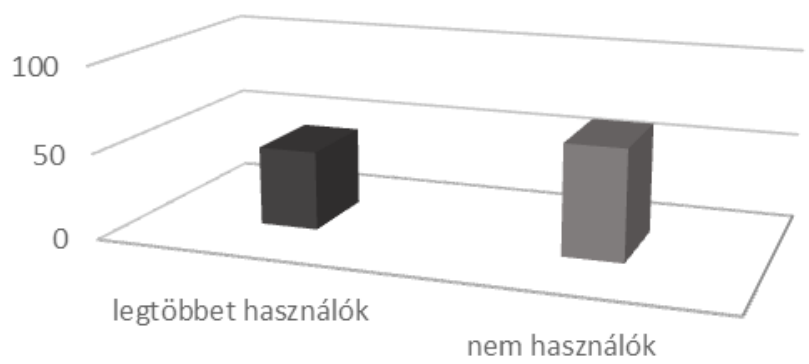

4. ábra. Halálszorongás skála összértékének különbségei vágott csoportban, nem fogyasztók, és legtöbbet fogyasztók esetén

Harmadik hipotézisünk, amely szerint a Koherencia-érzés skála (Balajti és mtsai, 2007) (Sense of Coherence Scale, SOC) magasabb értéket mutat majd a pszichedelikus szert használóknál a szert sosem próbálókhoz képest, nem tudtuk bizonyítani, hipotézisünkkel éppen ellentétes eredményt kaptunk, azaz a kontroll csoport magasabb koherencia-értéket mutatott, a meaningfulness (értelmesség) alskála esetén pedig szignifikáns eredményt kaptunk a szert nem használók javára (ld. később).

A teljes csoportban elvégzett kétmintás-t- próba alkalmazása során sem a normalitás, sem a szórás nem sérült, így kétmintás-t-próbát alkalmaztunk. Ennek eredménye $t(78)=-1,942(p=0,0557)+$ tendenciaszerü együtt járást mutatott pszichedelikus szert nem használók javára. (ld. 5. ábra)

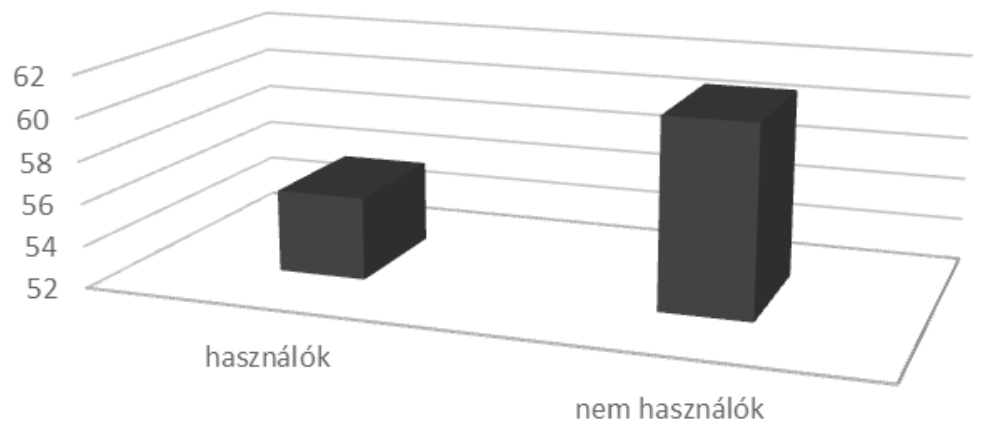

5. ábra. Koherencia-érzék átlagértékei a pszich és kontroll csoportban

A differenciált csoporton elvégzett varianciaanalízis lefuttatásakor sem a normalitás, sem a szórás nem sérült, eredménye azonban $(\mathrm{F}(2 ; 77)=2,205(\mathrm{p}=$ o,1172)) szignifikanciát nem mutatott. 
A vágott csoporttal végzett tesztelés szignifikáns eredményt szintén nem hozott a két csoport között végzett kétmintás t-próbával: $t(22)=-1,402(p=0,1747)$.

A teljes csoportban talált tendenciaszerű együtt járás kíváncsivá tett minket, ezért teszteltük az SOC alskáláit is, és az értelmesség (meaningfulness) alskálán teljes csoport esetében erős szignifikáns eredményt kaptunk. A lefuttatott kétmintás-t-próba mind ferdeség-csúcsosságban, mind pedig szóráshomogenitásban sérülést mutatott (Levene-próba: $\left.\mathrm{F}(1 ; 78,0)=4,112(\mathrm{p}=0,0460)^{*}\right)^{* *}$ ) így Welch-féle d-próbát alkalmaztunk, melynek eredménye: Welch-féle d-próba: $d(71,3)=-3,493(p=0,0008)^{* * *}$. (6. ábra.)

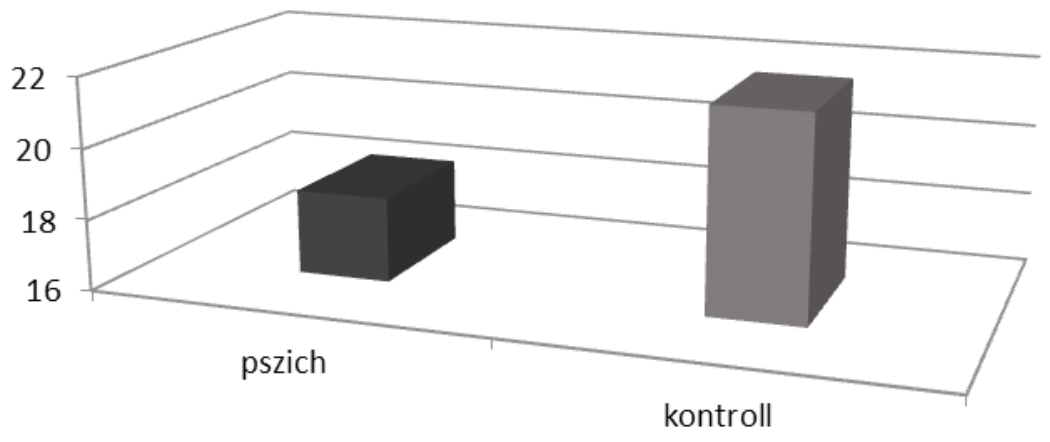

6. ábra. SOC Meaningfulness alskála eredmény teljes csoportban

A differenciált csoportos varianciaanalízis eredménye is szignifikanciát mutatott. Itt a szóráshomogenitás nem, de a normalitás sérült, így Kruskal-Wallispróbát végeztünk, melynek eredménye: $\mathrm{H}(2)=10,876(\mathrm{p}=0,0043)^{* *}$. (ld. 7 . ábra).

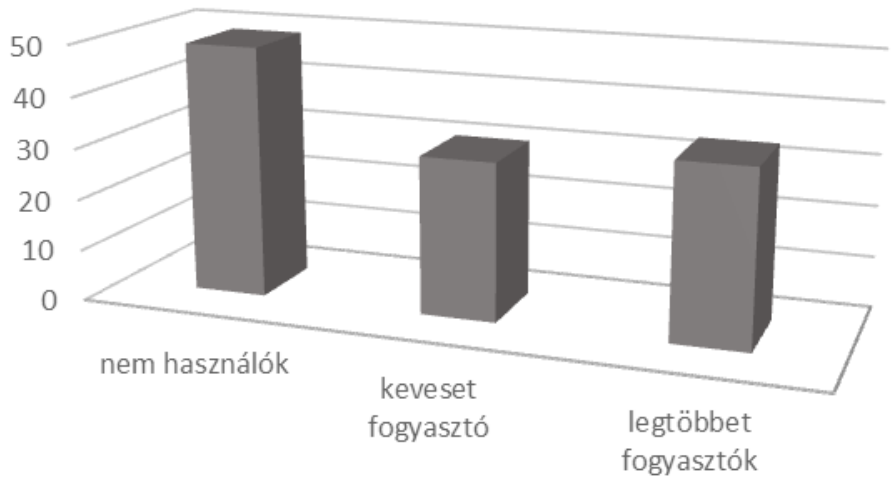

7.ábra. Csoportok átlagértékei (differenciált csoport esetén) az SOC meaningfulness alskálán 
Itt is figyelemreméltó eredmény, hogy éppúgy, mint a Lester-skálánál, a keveset fogyasztók mutatják a három csoport között a legalacsonyabb eredményt.

A „vágott” csoportban viszont szignifikáns eltérést nem, csupán tendenciaszerú együtt járást kaptunk a két csoport, azaz a legtöbbet használók és a kontroll csoport között.

A következő összefoglaló táblázatban (8. ábra) láthatóak az egyes csoportokban kapott lefutatott statisztikai próbák eredménye.

\begin{tabular}{|c|c|c|c|c|c|c|c|}
\hline \multicolumn{8}{|c|}{ Teljes csoport (kontroll $n=40$, pszich $n=40$ ) } \\
\hline & \multicolumn{2}{|c|}{ pszich } & \multicolumn{4}{|c|}{ kontroll } & \multirow[t]{2}{*}{ p érték } \\
\hline & átlag & szórás & \multicolumn{2}{|c|}{ átlag } & \multicolumn{2}{|l|}{ szórás } & \\
\hline SOC & 56,38 & 8,884 & & 59,85 & & 7,055 & $0,0557+$ \\
\hline SOC Meaningfulness & 18,4 & 4,866 & & 21,73 & & 3,544 & $0,0008 * * *$ \\
\hline $\begin{array}{r}\text { Lester } \\
\end{array}$ & 46,01 & 17,31 & & 49,67 & & 19,56 & 0,379 \\
\hline Stroop & 41,05 & 23,2 & & 39,95 & & 23,56 & 0,832 \\
\hline \multicolumn{8}{|c|}{ Differenciált csoport2 (kontroll $n=40$, keveset használók n= 20, legtöbbet használók $n=20$ ) } \\
\hline & \multicolumn{2}{|c|}{ nem használók } & \multicolumn{2}{|c|}{ keveset használók } & \multicolumn{2}{|c|}{ legtöbbet használók } & p érték \\
\hline & átlag & szórás & átlag & szórás & \begin{tabular}{l|l} 
átlag & \\
\end{tabular} & szórás & \\
\hline SOC & 59,85 & 7,055 & 57,5 & 8,43 & 55,35 & 9,33 & 0,11 \\
\hline SOC Meaningfulness & 48,96 & 19,51 & 30,65 & 22,33 & 33,91 & 25,88 & $0,0043 * *$ \\
\hline Lester & 49,67 & 19,56 & 43,28 & 17,31 & 48,75 & 17,31 & 0,44 \\
\hline Stroop & 39,95 & 23,56 & 43,09 & 23,9 & 38,29 & 22,63 & 0,7943 \\
\hline \multicolumn{8}{|c|}{ "Vágott" csoport (kontroll n=12, legtöbbet használók n=12) } \\
\hline & \multicolumn{2}{|c|}{ nem használók } & \multicolumn{4}{|c|}{ legtöbbet használók } & p érték \\
\hline & átlag & szórás & \multicolumn{2}{|c|}{ átlag } & \multicolumn{2}{|l|}{ szórás } & \\
\hline $\mathrm{SOC}$ & 60,92 & 5,485 & & 55,92 & & 11,07 & 0,174 \\
\hline SOC Meaningfulness & 22,33 & 3,284 & & 18,75 & & 6,137 & $0,088+$ \\
\hline Lester & 63,95 & 20,15 & & 45,86 & & 14,39 & $0,019 *$ \\
\hline Stroop & 13,17 & 8,244 & & 11,83 & & 5,967 & 0,644 \\
\hline
\end{tabular}

8.ábra. Összefoglaló táblázat az egyes csoportokban lefuttatott statisztikai próbák eredményéről

\section{DISZKUSSZIÓ}

Kutatásunkban azt vizsgáltuk, hogy a pszichedelikus szert használóknál mérhetô-e alacsonyabb szintû halálszorongás és magasabb koherencia-érték a pszichedelikumokat nem használókhoz képest.

Az érzelmi Stroop reakcióidőt mérő tesztben (Saboonchi és mtsai, 1997; Lundh és Radon,1998) korábbi kutatási eredményeire alapozva vártunk alacsonyabb értéket a pszichedelikus szert használók Stroop interferencia értékeként, azonban jelen kutatás nem tudta igazolni ezt a feltevést. Ennek oka lehet a kis minta elemszám, valamint az, hogy jelen kutatásban mind minor mind pedig major szereket használók bekerültek. A kis elemszám miatt csoportillesztést sem tudtunk végezni, így a pszich csoportban jelenlévő férfi, és a kontroll csoportban lévő női túlsúly is jelentősen befolyásolhatja a végeredményt. Továbbá az is feltételezhető, hogy ha közvetlenül a pszichedelikus élmény után vizsgálnánk a pszichonautákat, szignifikánsabb eredményt kaphatnánk, de erre a mai 
szabályozások nem adnak lehetőséget. És végül, de nem utolsó sorban, külön kutatást volna érdemes szentelni az érzelmi Stroop teszt validitásának.

A Lester-féle halálszorongás skáláján kapott szignifikáns eredmények alátámasztották feltevésünk. Fontos megjegyezni, hogy ezen eltérés a vágott csoport esetén, azaz a szert legtöbbször használók és a kontroll csoport között érvényesült. A differenciált csoport szignifikáns eredményt nem mutatott, átlagok tekintetében a keveset fogyasztók mutatták az alacsonyabb átlagértéket a Lesterféle halálszorongás skálán a legtöbbet használókkal és a kontroll csoporttal szemben. Ez utóbbiak mutatták a legmagasabb értéket. Úgy tűnik tehát, hogy az utazások száma korrelálhat a halálszorongással. Azaz, az utazás előhozhat, épp a tripek tartalmi elemei miatt szorongást (több utazás- többszöri szembesülésmagasabb szorongás), és ahogyan tanulmányuk elején említettük, éppen ennek kiküszöbélésére (volna) fontos az élményintegráció. Egy újabb kutatással, ahol a szerhasználati mintázatok, szertípusok, használati gyakoriságot is vizsgálat alá vonnánk, kívánatos lenne ezt megerősíteni. Felmerülhet a kérdés, hogy a keveset fogyasztók „másra” használják a szert, mint a legtöbbet fogyasztók (rekreációs vs. szorongás csökkentés), azonban erre a kérdésre válaszul Móróék cikkére érdemes visszautalnunk, ami szerint „a pszichedelikumokat használók az önismereti, spirituális célt, míg más szert használók a szerhasználat rekreációs jellegét hangsúlyozták." (Móró és mtsai, 2011). A pszichedelikus szerek használatának motivációja alapvető eltérést mutat az egyéb drogok használatától.

A koherencia-érzés skálán kapott meglepő és ellentmondó értékek is további kutatásra ösztönöznek. Lerner és Lyvers eredményeinek (2006) ellentmondva teljes csoportban tendenciaszerű eltérést mutatott a statisztikai próba a kontroll csoport javára. Az értelmesség (meaningfulness) alskálán szintén a kontroll csoport javára mutatott szignifikáns eltérést a lefuttatott próba, és szignifikanciát mutatott a differenciált csoportban is, itt a keveset használók mutatták a legkisebb, a nem használók a legmagasabb értéket. Azonban „vágott” csoportos elrendezésben már csak csekély, tendenciaszerű eltérést figyeltünk meg a legtöbbet fogyasztók és a nem használók között. Sajnos azt nem állt módunkban kísérleti elrendezésünkben megfigyelni, hogy vajon a kevesebbet használó csoport tagjainak eredendően alacsonyabb volt- e koherencia-érzés mutatója, és talán épp ezért kísérleteztek pszichedelikumokkal, vagy esetlegesen magasabb értékről csökkent a szer hatására.

Érdemes elgondolkozni azon is, hogy csupán a meaningfulness alskála esetében kaptunk szignifikáns eltérést, azaz az élethelyzet átélt érthetősége (comprehensibility), az életproblémák reálisként érzett kezelhetősége (manageability) alskálák esetében a csoportok nemigen különböznek. További kutatásokban, ahogy fent említettük, a résztvevők körét érdemes volna csak major szereket használókra szúkíteni, valamint a teljes, 29 itemes SOC skálát használni, kiküszöbölendő az esetlegesen téves pozitív eredményeket. 
A major-minor szereket használók szétválasztásának szükségessége mellett megemlítendő, hogy a pszichedelikus szerhasználó csoport még pontosabb szürése, illesztése is jelentősen befolyásolhatta a kapott eredményt (pl. a férfiaknők aránya: A pszich csoportban: 4 nő, 36 férfi, a kontroll csoportban 31 nő, 9 férfi volt.) Jelen kutatás keretei között nem volt lehetőségünk sem szertípusok, sem a használat idejének, mértékének tekintetében szűrni a kutatásban résztvevők körét. Eredményesebb lehetne a kutatás kimenetele, ha a tesztfelvételt közvetlenül a pszichedelikus élmények után többször, valamint integrációt követően hosszabb távon, longitudinálisan lehetne lefolytatni, ám erre a mostani kutatási engedélyezési gyakorlat nem biztosít lehetőséget.

Továbbá megemlítendő, hogy kutatásunkban nem tértünk ki az élményintegrációra, ami szintén finomíthatná és pontosabbá tehetné az eredmények értelmezését, illetve az összefüggések megértését.

\section{FELHASZNÁLT IRODALOM}

Algom, D., Chajut, E., \& Lev, S. (2004). A rational look at the emotional stroop phenomenon: a generic slowdown, not a stroop effect. Journal of experimental psychology: General, 133(3), 323.

Antonovsky, A. (1987). Unraveling the mystery of health: How people manage stress and stay well. Jossey-Bass.

Ilona, B., Vokó, Z., Ádány, R., \& Karolina, K. (2007). A koherencia-érzés mérésére szolgáló rövidített kérdoív és a lelki egészség (GHQ-12) kérdoív magyar nyelvu változatainak validálása. Mentalhigiene es Pszichoszomatika, 8(2), 147-161.

Békés, V. (2004). A félelem megszelídítése - A Rettegéskezelés elmélete. Kharón Thanatológiai Szemle, 8(2004), 1-2.

Böszörményi, Z. (1958). Dimethyltryptamine experiments with psychotics. The British Journal of Psychiatry, 104(435), 445-453.

Böszörményi Z.: Psychotomimeticumok vizsgálata emberen. Orvostudomány 19,1968.

Demily, C., Attala, N., Fouldrin, G., Czernecki, V., Ménard, J. F., Lamy, S., ... \& Thibaut, F. (2010). The Emotional Stroop task: A comparison between schizophrenic subjects and controls. European Psychiatry, 25(2), 75-79.

Fiske, S. T., Gilbert, D. T., \& Lindzey, G. (Eds). Handbook of Social Psychology (5th Ed.). New York; McGraw-Hill, 2004.

Gasser, P., Kirchner, K., \& Passie, T. (2015). LSD-assisted psychotherapy for anxiety associated with a life-threatening disease: a qualitative study of acute and sustained subjective effects. Journal of Psychopharmacology, 29(1), 57-68.

Christian, J. (1976). The psychedelic model of schizophrenia: the case of N, N-dimethyltryptamine. Am J Psychiatry, 133(2).

Greenberg, J., Pyszczynski, T., \& Solomon, S. (1986). The causes and consequences of a need for selfesteem: A terror management theory. In Public self and private self (pp. 189-212). Springer New York. 
Grob, C. S., Danforth, A. L., Chopra, G. S., Hagerty, M., McKay, C. R., Halberstadt, A. L., \& Greer, G. R. (2011). Pilot study of psilocybin treatment for anxiety in patients with advanced-stage cancer. Archives of general psychiatry, 68(1), 71-78.

Grob, C. S., Winkelman, M. J., \& Roberts, T. B. (2007). The use of psilocybin in patients with advanced cancer and existential anxiety. Psychedelic Medicine: New Evidence for Hallucinogenic Substances as Treatment. Westport, CT: Praeger, 205-216.

Grof, S., \& Halifax, J. (1977). The human encounter with death. New York: E.P. Dutton, http:// selfdefinition.org/afterlife/Stanislav-Grof-Human-Encounter-With-Death.pdf. Letöltés: 2016. február 18;

Grof, S., Goodman, L. E., Richards, W. A., \& Kurland, A. A. (1973). LSD-assisted psychotherapy in patients with terminal cancer. International pharmacopsychiatry, 8(3), 129-144.

Horváth, L., Szummer, C., \& Szabo, A. (2017). Weak phantasy and visionary phantasy: the phenomenological significance of altered states of consciousness. Phenomenology and the Cognitive Sciences, 1-13.

Masters, R., \& Houston, J. (2000). The varieties of psychedelic experience: the classic guide to the effects of LSD on the human psyche. Inner Traditions/Bear \& Co.

Kirkegaard, S.: Søren Kierkegaard írásaiból. Budapest: Gondolat, 1969.

Kirkegaard, S.: A szorongás fogalma. Budapest: Göncöl Kiadó, 1993.

Larsen, R. J., Mercer, K. A., \& Balota, D. A. (2006). Lexical characteristics of words used in emotional Stroop experiments. Emotion, 6(1), 62.

Leary, T. (1966). Programmed communication during experiences with DMT. Psychedelic Review, 8, 83-95.

Lester, D. (1991). The Lester attitude toward death scale. OMEGA-Journal of Death and Dying, 23(1), 67-75.

Lerner, M., \& Lyvers, M. (2006). Values and beliefs of psychedelic drug users: A cross-cultural study. Journal of psychoactive drugs, 38(2), 143-147.

Lundh, L. G., \& Radon, V. (1998). Death anxiety as a function of belief in an afterlife. A comparison between a questionnaire measure and a Stroop measure of death anxiety. Personality and Individual Differences, 25(3), 487-494.

Masters, R., \& Houston, J. (2000). The varieties of psychedelic experience: the classic guide to the effects of LSD on the human psyche. Inner Traditions/Bear \& Co.

Mirnics Zs. (2016): Pszichedelikus szerek terápiás alkalmazása: lehetőségek, kihívások. in: SepsiDeres-Szummer (szerk). Studia Caroliensia 2016. pp. 230-248

Móró, L., Simon, K., Bárd, I., \& Rácz, J. (2011). Voice of the psychonauts: Coping, life purpose, and spirituality in psychedelic drug users. Journal of Psychoactive Drugs, 43(3), 188-198.

Pahnke, W. N. (1966). Drugs and mysticism. International Journal of Parapsychology, 8(2), 295313 .

Pahnke, W. N. (1969). The psychedelic mystical experience in the human encounter with death. Harvard Theological Review, 62(01), 1-21.

Pahnke, W. N., Kurland, A. A., Unger, S., Savage, C., \& Grof, S. (1970). The experimental use of psychedelic (LSD) psychotherapy. Jama, 212(11), 1856-1863.

Popovics J., Szummer Cs., Ocsovszky Zs.: A pszichedelikus élmény egzisztenciális kontextusban. In: 
A szél fúj, ahová akar (szerk. F. J., Mészáros Márton, Tóth Dóra). Károli Gáspár Református Egyetem - L’Harmattan Kiadó, Budapest, 2016.

Rappant, Gy. (1992/2002). Hallucinogén vegyületek (DMT, DET) kísérleti alkalmazása. http://www. daath.hu/showText.php?id=73. Letöltve: 2016. február 18 .

Saboonchi, F., \& Lundh, L. G. (1997). Perfectionism, self-consciousness and anxiety. Personality and Individual Differences, 22(6), 921-928.

Simon K. (2009) Pszichedelikus drogokat önismereti célzattal használók életminősége. Szakdolgozat.

Strassman, R. J., Qualls, C. R., \& Berg, L. M. (1996). Differential tolerance to biological and subjective effects of four closely spaced doses of N, N-dimethyltryptamine in humans. Biological psychiatry, 39(9), 784-795.

Strassman, R. J. (1995). Human psychopharmacology of N, N-dimethyltryptamine. Behavioural brain research, 73(1), 121-124.

Strassman, R. (2000). DMT: The spirit molecule: A doctor's revolutionary research into the biology of near-death and mystical experiences. Inner Traditions/Bear \& Co.

Szabo A., Horvath L., Szummer Cs. (2014). Phenomenology and altered states of consciousness: a new framework for analysis? Psychologia Hungarica Caroliensis, 2:7-29

Szigethy K., Takács Sz. (2016). Figyelemfelhívás egy hibás publikációra és javaslat korrekcióra. Psychologia Hungarica Caroliensis, 3:(2)

Szummer Cs. (2011a). A pszichedelikus élmény pszichológiai megközelítései. LAM (Lege Artis Medicinae). 21(5):404-408.

Szummer Cs. (2012b). A pszichedelikumokban rejlő veszélyek és lehetőségek. LAM (Lege Artis Medicinae) 22 (3):164-167.

Szummer Cs. (2015a). A pszichedelikus élmény változatai. Psychologia Hungarica Caroliensis. 2:12-30

Szummer Cs. (2015b). Pszichedelikumok és spiritualitás. Budapest, L’Harmattan.

Szummer Cs. (2016). LSD és más “csodaszerek”. HVG Kiadó, Budapest.

Szummer Cs. (2010). Az LSD és a transzcendens élmények. Addiktológia 8:1.

Szummer Cs. (2012). Pszichedelikumok és kvázi-misztikus élmények. LAM (Lege Artis Medicinae). $22(2)$

Szummer Cs. (2015c). A pszichedelikus élmény mint a fenomenológiai kutatás eszköze a filozófiában és a pszichológiában. Magyar Filozófiai Szemle 2: 161-183

Takács Sz. (2013). Statisztikai segédanyag műhelymunkákhoz, szakdolgozatokhoz. L’Harmattan Kiadó, Budapest. ebook, letöltve 2016. Január 13.

Takács Sz. (2012). Érzékenységvizsálatok a statisztikai eljárásokban. Alkalmazott Matematikai Lapok 29(1).

Tillich, P.(1952). The courage to be. New Haven \& London University Press. http://www.polts.com/ Research_files/Source\%20Material/Tillich/courageofbeo11129mbp.pdfLetöltve 2016. Szeptember 30 .

Tóthné Z. Á. (2009) A halálkép alakulása és változása Magyarországon, a korosztályos értékítéletkülönbségek és a lehetséges mérési módszerek vizsgálata. Tabu-e még a halál? Doktori értekezés. SOTE.

Van Deurzen, E. (2009). Everyday Mysteries: Existential Dimensions of Psychotherapy. London, Routledge; 2nd edition. 


\section{OCSOVSZKY ZSÓFIA - POPOVICS JUDIT}

Vargha A. (2000). Matematikai Statisztika Pszichológiai, nyelvészeti és biológiai alkalmazásokkal. Pólya Kiadó, Budapest.

Watts, F. N., McKenna, F. P., Sharrock, R., \& Trezise, L. (1986). Colour naming of phobia $\square$ related words. British journal of Psychology, 77(1), 97-108.

Williams, J. M. G., Mathews, A., \& MacLeod, C. (1996). The emotional Stroop task and psychopathology. Psychological bulletin, 120(1), 3 .

Williams, J. M. G., \& Nulty, D. D. (1986). Construct accessibility, depression and the emotional stroop task: Transient mood or stable structure?. Personality and Individual Differences, 7(4), 485-491.

Yalom, I.D. (2006). Egzisztenciális pszichoterápia. Budapest, Animula. 